\title{
Improvement of Lung Preservation - From Experiment to Clinical Practice
}

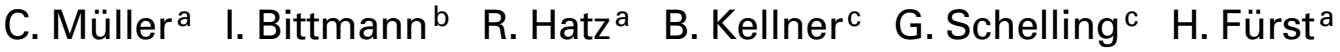 \\ B. Reichart ${ }^{d}$ F.W. Schildberg ${ }^{a}$ \\ a Department of Surgery, bInstitute of Pathology, ${ }^{\mathrm{c} C l i n i c}$ of Anaesthesiology, and dDepartment of Cardiac Surgery, \\ Ludwig Maximilians University, Klinikum Grosshadern, Munich, Germany
}

\section{Key Words}

Lung preservation $\cdot$ Reperfusion injury $\cdot$ Euro-Collins solution - Low potassium dextran

\begin{abstract}
Background: Reperfusion injury represents a severe early complication following lung transplantation. Among the pathogenetic factors, the high potassium content of Euro-Collins ${ }^{\circledR}$ solution is discussed. Material and Methods: In a pig model of orthotopic left-sided lung transplantation we investigated the effect of Euro-Collins solution (EC: $n=6$ ) versus low potassium dextran (LPD: Perfadex $\left.{ }^{\circledR}: n=6\right)$. Sham-operated $(n=6)$ animals served as control. Transplant function, cellular energy metabolism and endothelial morphology served as parameters. In a clinical investigation, 124 patients were evaluated following single (EC: $n=31$; LPD $n=37$ ) or double (EC: $n=$ 17; LPD $\mathrm{n}=39$ ) lung transplantation, whose organs where preserved with EC $(n=48)$ or LPD $(n=76)$. Duration of ischemia, duration of ventilation and stay on ICU were registered. Primary transplant function was evaluated according to $\mathrm{AaDO}_{2}$ values. Cause of early death (30
\end{abstract}

The experimental study was sponsered by Sander Foundation.

\section{KARGER}

Fax + 41613061234

E-Mail karger@karger.ch

www. karger.com
(C) 2002 S. Karger AG, Basel

0014-312X/02/0342-0077\$18.50/0

Accessible online at:

www. karger.com/journals/esr days) was declared. Results: Experimental results: After flush with EC and $18 \mathrm{~h}$ ischemia, a reduction of tissue ATP content ( $p<0.01$ vs inital value and LPD) was noted. Endothelial damage after ischemia was severe $(p<0.05$ vs control), $\mathrm{paO}_{2}$ was significantly decreased. Clinical results: In the LPD group, duration of ischemia was Ionger for the grafts transplanted first (SLTx and DLTx: $p=$ 0.0009 ) as well as second (2. organ DLTx: $p=0.045$ ). Primary transplant function was improved (day 0: SLTx: $p=$ 0.0015; DLTx: $p=0.0095$, both vs EC). Duration of ventilation and stay on ICU were shorter (n.s.). Reperfusion injury-associated death was reduced from $8 \%$ (EC) to 0 (LPD). Conclusion: In experimental lung preservation, LPD lead to an improved graft function. These results were confirmed in clinical lung transplantation. Clinical lung preservation, therefore, should be carried out by use of LPD.

Copyright $\odot 2002$ S. Karger AG, Basel

\section{Introduction}

Since the first successfully performed lung transplantation in man by Hardy and colleagues [1] in 1963 this therapeutic approach has become a standard procedure for the therapy of end-stage pulmonary disease. Up to date

PD Dr. Ch. Müller

Department of Surgery, Ludwig Maximilians University

Klinikum Grosshadern, Marchioninistrasse 15

D-81377 Munich (Germany), Tel +49 897095 3511, Fax +49 8970953508

E-Mail christian.mueller@gch.med.uni-muenchen.de 
Table 1. Metabolic state and endothelial integrity of native lungs (A), after ischemia (B) and reperfusion (C)

\begin{tabular}{|c|c|c|c|c|c|c|}
\hline & \multirow{2}{*}{$\begin{array}{l}\text { A } \\
(n=12)\end{array}$} & \multicolumn{2}{|l|}{ B } & \multicolumn{3}{|l|}{$\mathrm{C}$} \\
\hline & & $\mathrm{EC}(\mathrm{n}=6)$ & $\operatorname{LPD}(n=6)$ & Sham $(n=6)$ & $\mathrm{EC}(\mathrm{n}=6)$ & $\operatorname{LPD}(n=6)$ \\
\hline ATP, $\mu \mathrm{mol} / \mathrm{g} \mathrm{dw}$ & $9.4 \pm 0.4$ & $6.8 \pm 1.6^{*}$ & $8.2 \pm 1.1$ & $7.2 \pm 0.7$ & $7.6 \pm 2.0$ & $6.0 \pm 1.0$ \\
\hline $\mathrm{SAN}, \mu \mathrm{mol} / \mathrm{g} \mathrm{dw}$ & $12.9 \pm 0.3$ & $11.8 \pm 2.2$ & $12.7 \pm 1.1$ & $09.6 \pm 1$ & $10.8 \pm 1.1$ & $9.7 \pm 1.4$ \\
\hline ECP & $0.82 \pm 0.02$ & $0.69 \pm 0.06 *$ & $0.75 \pm 0.03$ & $0.85 \pm 0.02$ & $0.72 \pm 0.06$ & $0.74 \pm 0.02$ \\
\hline $\mathrm{PCr} / \mathrm{tCr}$ & $0.34 \pm 0.03$ & $0.25 \pm 0.06$ & $0.38 \pm 0.04$ & $0.23 \pm 0.03$ & $0.24 \pm 0.03$ & $0.4 \pm 0.03$ \\
\hline Glucose, $\mu \mathrm{mol} / \mathrm{g} \mathrm{dw}$ & $23.9 \pm 1.8$ & $133 \pm 33^{* *}$ & $3.7 \pm 0.6$ & $13.3 \pm 2.7$ & $33.0 \pm 4^{\# \#}$ & $16.2 \pm 4$ \\
\hline Lactate, $\mu \mathrm{mol} / \mathrm{g} \mathrm{dw}$ & $14.4 \pm 1.4$ & $48.8 \pm 6.1^{* *}$ & $23.5 \pm 2.2$ & $20.8 \pm 3.9$ & $33.6 \pm 7.2^{\#}$ & $25.6 \pm 5.2$ \\
\hline Endothelium & $1.7 \pm 0.2$ & $3 \pm 0.3^{+}$ & $1.8 \pm 0.4$ & $3.7 \pm 0.3^{* *}$ & $4 \pm 0.4^{* *,++}$ & $3.7 \pm 0.2 * *, * * *$ \\
\hline
\end{tabular}

SAN = Sum of adenine nucleotides $; \mathrm{ECP}=$ energy charge potential; ${ }^{+} \mathrm{p}<0.05 \mathrm{vs} \mathrm{A} ;{ }^{++} \mathrm{p}<0.05 \mathrm{vs} \mathrm{B} ;{ }^{*} \mathrm{p}<0.01 \mathrm{vs}$ $\mathrm{A} ;{ }^{* *} \mathrm{p}<0.0001$ vs $\mathrm{A} ;{ }^{* * *} \mathrm{p}<0.0001$ vs $\mathrm{B} ;{ }^{\#} \mathrm{p}<0.05$ vs $\mathrm{A}$ und $\mathrm{B} ;{ }^{\# \#} \mathrm{p}<0.001$ vs $\mathrm{B}$. All values are mean $\pm \mathrm{SD}$.

more than 12,000 lung transplantations have been performed world-wide [2]. An essential factor determining the outcome following lung transplantation is organ preservation. Most lung transplanting centers around the world use Euro-Collins ${ }^{\circledR}$ (EC) solution for flush perfusion of donor organs. This method of organ preservation leads to ischemia-reperfusion injury (IRI) in more than $50 \%$ of all organs with an ensuing mortality rate as high as $5 \%$ [3-5].

As major pathogenetic factor the high potassium content of the Euro-Collins solution has been discussed, which induces a strong vasoconstriction of the pulmonary vessel bed [6] and reduces the vascular relaxation capacity of pulmonary vessels [7].

Experimental studies have shown that the use of a lowpotassium dextran (LPD: Perfadex ${ }^{\circledR}$ ), which is an extracellular preservation solution containing dextran as osmotic active component results in an improved primary transplant function $[8,9]$.

In our clinical experience the use of Euro-Collins preservation solution causes an ischemia-reperfusion injury in $65 \%$ with a mortality rate of $6 \%$. Prior to introduction of low-potassium dextran solution as an alternate preservation fluid in the clinical practice we therefore evaluated the solution in a bovine model of orthotopic left-sided lung transplantation [10].

\section{Material and Method}

\section{Experimental Studies}

In a model of orthotopic left-sided single lung transplantation native pigs of either sex were paired by weight. Twelve pigs served as donors, 12 pigs served as recipient animals. The donor organs were preserved by Euro-Collins solution $(n=6)$ or low-potassium dextran $(\mathrm{n}=6)$ alternatively. A group of sham-operated animals served as control $(n=6)$. The experimental protocol was approved by the government of Oberbayern.

\section{Donor Procedure}

Under general anesthesia heparin sodium was administered intravenously $(500 \mathrm{IE} / \mathrm{kg}$ ) followed by intravenous application of Epoprostenol $(200 \mu \mathrm{g})$. After induction of cardiac arrest both lungs were perfused with pre-chilled Euro-Collins solution (EC: $\mathrm{n}=6 ; 150 \mathrm{ml} / \mathrm{kg}$ b.w.) or low-potassium dextran (LPD; $\mathrm{n}=6,150 \mathrm{ml} / \mathrm{kg}$ b.w.) with a perfusion pressure of $50 \mathrm{~cm}$ water. Ventilation was continued during the flush procedure, at the end of the perfusion both lungs were explanted, dissected free from surrounding tissue and preserved in Ringer solution $\left(4^{\circ} \mathrm{C}\right)$ while insufflated with pure oxygen.

\section{Recipient Procedure}

Following $18 \mathrm{~h}$ of ischemia a left-sided single lung transplantation was performed in both groups. A group of sham-operated animals $(n=6)$ served as control. Serial measurements of the pulmonary and systemic hemodynamics (MAP) and calculation of the pulmonary vascular resistance (PVR) were carried out right before the transplantation and every hour during the reperfusion period. Measurements were performed in the single lung ventilation and perfusion state, excluding the native lung from perfusion and ventilation by clamping of the right hilus.

For metabolic analysis biopsies from the apex of the upper lobe were taken from normal lungs (A: left recipient lung prior to pneumonectomy), at the end of preservation (B: right preserved lung) and at the end of reperfusion ( $\mathrm{C}$ : transplanted lung). Probes were shockfrozen and processed for enzymatic tests, determining tissue levels of adenosine triphosphate (ATP), glucose and lactate. Sum of adenine nucleotides (SAN = ATP + ADP + AMP) and energy charge potential $(\mathrm{ECP}=\mathrm{ATP}+0.5 \mathrm{ADP} / \mathrm{SAN})$ were calculated. Morphological analysis was carried out on biopsies of four lung areas. Endothelial cell integrity was evaluated and classified as 0 (normal structure) up to 5 (severe endothelial damage with loss of endothelial cells). Biopsies were taken from non-treated lungs (A: left lung of recipient prior to pneumonectomy), at the end of ischemia (B: donor right lung) and at the end of reperfusion (C: lung graft). 
Table 2. Pulmonary hemodynamic and gas exchange

\begin{tabular}{|c|c|c|c|c|c|c|c|}
\hline & \multirow{2}{*}{$\begin{array}{l}\text { pre Tx } \\
(\mathrm{n}=24)\end{array}$} & \multicolumn{3}{|c|}{$1 \mathrm{~h}$ post reperfusion } & \multicolumn{3}{|c|}{$6 \mathrm{~h}$ post reperfusion } \\
\hline & & Sham $(n=6)$ & $\mathrm{EC}(\mathrm{n}=4)$ & $\operatorname{LPD}(\mathrm{n}=6)$ & Sham $(n=6)$ & $\mathrm{EC}(\mathrm{n}=6)$ & $\operatorname{LPD}(n=6)$ \\
\hline $\mathrm{MAP}, \mathrm{mmHg}$ & $84 \pm 5$ & $98 \pm 10$ & $77 \pm 10$ & $89 \pm 6$ & $87 \pm 6$ & $68 \pm 12$ & $78 \pm 10$ \\
\hline $\mathrm{PVR}, \mathrm{dyn} \cdot \mathrm{s} \cdot \mathrm{cm}^{-5}$ & $387 \pm 30$ & $445 \pm 28$ & $2,056 \pm 1,092 *, * *$ & $830 \pm 118$ & $748 \pm 63$ & $1,787 \pm 380^{\#}$ & $1,670 \pm 177$ \\
\hline $\mathrm{PaO}_{2}, \mathrm{~mm} \mathrm{Hg}$ & $458 \pm 15$ & $478 \pm 38$ & $374 \pm 99$ & $325 \pm 75$ & $492 \pm 43$ & $276 \pm 81^{\#, \# \#}$ & $436 \pm 47$ \\
\hline
\end{tabular}

PVR = Pulmonary vascular resistance; ${ }^{*} \mathrm{p}<0.05$ vs LPD; ${ }^{* *} \mathrm{p}<0.01$ vs sham; ${ }^{*} \mathrm{p}<0.05$ vs sham;

$\#$ \# $<0.01$ vs $L P D ;$ all values as mean \pm SD.

\section{Statistics}

Data are group mean \pm SEM. Results obtained from functional, morphological and metabolic parameters were statistically analyzed using ANOVA and Fisher's exact test. Dependent variables were tested by Student's t test. Differences between groups were considered significant at $\mathrm{p}<0.05$.

\section{Results}

A significant decrease of ATP and ECP vs. non-treated lungs of group A was observed in the EC-preserved animals at the end of ischemia. The tissue content of glucose and lactate was significantly increased. All other groups showed a clear decrease of the glucose content and an increase of tissue lactate concentration (NS). At the end of reperfusion parameters of the energy metabolism did not show significant differences when compared with the initial values. Endothelial cells from lungs of group A were unaltered and showed a discrete swelling in some cases (table 1).

After $18 \mathrm{~h}$ of ischemia lungs perfused with Euro-Collins solution showed a significant increase in endothelial cell swelling with a vacuolisation of the cells. Lungs of the LPD group were not significantly altered as compared to group A. At the end of reperfusion (C) all lungs of the study groups showed medium to severe endothelial alterations.

After $1 \mathrm{~h}$ of reperfusion 4 of 6 animals of the EC-group and all animals of the LPD group $(n=6)$ tolerated the clamping of the right native lung. Oxygenation capacity and MAP did not show significant differences, the PVR was highest in the EC group. After $6 \mathrm{~h}$ of reperfusion functional measurements were carried out in all animals of both groups. In the EC group $\mathrm{paO}_{2}$ was lowest and PVR highest, the LPD group showed PVR values significantly increased compared to the initial values (table 2).
Table 3. Donor data

\begin{tabular}{llll}
\hline & EC $(\mathrm{n}=48)$ & $\mathrm{LPD}(\mathrm{n}=76)$ & $\mathrm{p}$ \\
\hline Age, years & $31 \pm 11$ & $35 \pm 12$ & \\
Gender & & & \\
$\quad$ Male & 27 & 40 & \\
$\quad$ Female & 21 & 36 & \\
Cause of death & & & \\
$\quad$ Brain injury & 26 & 34 & \\
$\quad$ SAB & 15 & 28 & \\
$\quad$ Others & 7 & 14 & 0.0009 \\
Duration of ischemia, h & & & \\
$\quad$ 1. lung & $4.2 \pm 1.0$ & $4.9 \pm 1.0$ & \\
$\quad$ 2. lung & $6.0 \pm 1.6$ & $6.9 \pm 1.4$ & 0.045 \\
\hline
\end{tabular}

Mean \pm SD

\section{Patients and Methods}

Since the first lung transplantation in our institution in August 1991, 141 lung transplantations were performed in 138 patients until September 2001. Since not all donor organs were explanted by our own team, $12 \%(n=17)$ of the donor organs were preserved by means of other than Euro-Collins or low-potassium dextran solution. This analysis focuses on the 124 patients where donor organs were preserved using Euro-Collins $(n=48)$ or low-potassium dextran $(\mathrm{n}=76)$.

The analysis of donor data showed a similar distribution of age, gender and causes of death. In the LPD-group duration of ischemia was significantly longer when compared with the Euro-Collins-preserved organs (table 3).

Transplantations were performed in 70 female and 54 male patients, with a significantly lower mean recipient age in the EC group.

The leading indications for lung transplantation were pulmonary fibrosis, emphysema and cystic fibrosis (CF). 
Table 4. Parameters of organ recipients

\begin{tabular}{lll}
\hline & EC $(\mathrm{n}=48)$ & LPD $(\mathrm{n}=76)$ \\
\hline Age, years & $41 \pm 13$ & $46 \pm 12^{*}$ \\
Gender & 23 & 31 \\
$\quad$ Male & 25 & 45 \\
$\quad$ Female & & \\
Disease & 20 & 24 \\
$\quad$ Fibrosis & 13 & 28 \\
Emphysema & 11 & 10 \\
CF & 4 & 14 \\
Others & & \\
Tx-Type & 31 & 37 \\
$\quad$ SLTx & 17 & 39 \\
DLTx & & \\
\hline
\end{tabular}

SLTx $=$ Single lung transplantation; DLTx $=$ double lung transplantation; $\mathrm{CF}=$ cystic fibrosis; ${ }^{*} \mathrm{p}<0.0001 ;$ all values are mean \pm SD.

Table 5. Postoperative course of all patients

\begin{tabular}{lccl}
\hline & $\mathrm{EC}(\mathrm{n}=48)$ & $\mathrm{LPD}(\mathrm{n}=76)$ & $\mathrm{p}$ \\
\hline $\mathrm{AaDO}_{2}$ (day 0) & $276 \pm 170$ & $173 \pm 136$ & 0.0004 \\
$\mathrm{AaDO}_{2}$ (day 1) & $143 \pm 135$ & $118 \pm 116$ & $\mathrm{~ns}$ \\
$\mathrm{AaDO}_{2}$ (day 3) & $100 \pm 117$ & $73 \pm 54$ & $\mathrm{~ns}$ \\
Ventilation (days) & $21 \pm 45$ & $11 \pm 15$ & $\mathrm{~ns}$ \\
Stay on ICU (days) & $33 \pm 48$ & $21 \pm 22$ & $\mathrm{~ns}$ \\
\hline
\end{tabular}

Mean \pm SD
Rare indications were lymphangioleiomyomatosis $(\mathrm{n}=5)$, pulmonary hypertension $(n=5)$, exogeneous allergic alveolitis $(n=2)$, cystic lung disease $(n=2)$, bronchiectasis $(\mathrm{n}=1)$ and obliterative bronchiolitis $(\mathrm{n}=2)$. One transplantation was carried out as re-transplantation due to primary graft failure.

Single-lung transplantation was carried out in 68 cases, while double-lung transplantation was necessary in 56 patients (table 4).

The postoperative graft function was evaluated according to the calculated alveolar arterial oxygen pressure difference $\left(\mathrm{AaDO}_{2}\right)$.

In the LPD group a significantly lower $\mathrm{AaDO}_{2}$ was observed during the first $24 \mathrm{~h}$ following transplantation. The subsequently better gas exchange function allowed for a shorter duration of ventilator therapy and a shorter intensive care unit stay in patients receiving LPD-preserved organs (table 5).

Comparison of the LPD and Euro-Collins group indicates comparable length of surgery, blood transfusion requirements and a significantly improved gas exchange despite significantly more patients requiring extracorporeal circulation in the LPD-group during surgery. This observation was independent of single-lung or doublelung transplantation (table 6).

30-day mortality in the LPD group was lower than in the EC group. The development of severe ischemia reperfusion injury led to the death of 3 patients in the EC group, while after introduction of low-potassium dextran as preservation medium severe reperfusion injuries were no more seen (table 7).
Table 6. Intra- und postoperative course following single- (SLTx) and double lung transplantation (DLTx)

\begin{tabular}{|c|c|c|c|c|}
\hline & \multicolumn{2}{|l|}{ SLTx } & \multicolumn{2}{|l|}{ DLTx } \\
\hline & $\mathrm{EC}(\mathrm{n}=31)$ & $\operatorname{LPD}(n=32)$ & $\mathrm{EC}(\mathrm{n}=17)$ & $\operatorname{LPD}(\mathrm{n}=38)$ \\
\hline Duration of operation, min & $223 \pm 157$ & $191 \pm 121$ & $367 \pm 104$ & $347 \pm 156$ \\
\hline Blood units & $2.2 \pm 5.0$ & $1.5 \pm 3.1$ & $6.8 \pm 5.0$ & $6.4 \pm 6.8$ \\
\hline HLM (\%) & 16 & 31 & 47 & 50 \\
\hline $\mathrm{AaDO}_{2}$ (day 0) & $232 \pm 142$ & $140 \pm 88 *$ & $336 \pm 191$ & $201 \pm 163^{* *}$ \\
\hline $\mathrm{AaDO}_{2}$ (day 1 ) & $140 \pm 129$ & $110 \pm 85$ & $141 \pm 150$ & $126 \pm 138$ \\
\hline $\mathrm{AaDO}_{2}$ (day 3) & $101 \pm 113$ & $71 \pm 53$ & $98 \pm 126$ & $74 \pm 56$ \\
\hline Ventilation (days) & $18 \pm 41$ & $7 \pm 10$ & $25 \pm 54$ & $14 \pm 17$ \\
\hline
\end{tabular}




\section{Discussion}

The development of ischemia-reperfusion injury following lung transplantation leads to increased morbidity and mortality rates. Clinical standard in most transplanting centers for the prevention of this severe condition is the administration of heparin and vasodilatory agents, followed by pulmonary flush perfusion with pre-chilled Euro-Collins solution. Use of this method leads to the development of an ischemia-reperfusion injury in more than $50 \%$ of all patients, which may cause a mortality rate as high as 5\% [5]. In our institution the use of Euro-Collins solution was responsible for reperfusion injury in $60 \%$ of our patients with a subsequent mortality rate of $8 \%$.

Reports in the literature have indicated that the use of low-potassium dextran (Perfadex) as preservation medium might be beneficial when compared to Euro-Collins solution. As pathophysiological rationale for the development of an ischemia-reperfusion injury by use of EuroCollins solution, a direct effect of the high-potassium content of Euro-Collins on endothelial cells of the pulmonary vasculature has been discussed [6]. An observed increase of the pulmonary vascular resistance during reperfusion seemed to be caused by a reduction of endothelial NO synthesis, which by means of reduction of the vascular relaxation capacity may lead to an increase of their resistance $[7,14]$. Experimental studies on isolated pulmonary artery segments by Kimblad and co-workers [15] showed a significantly improved relaxation capacity of these vessels after preservation with low-potassium dextran. Analysis of isolated type-II pneumocytes showed a decreased cytotoxicity after use of LPD [16]. In our own experimental studies using a model of orthotopic left-sided singlelung transplantation in pigs a significantly improved graft function was observed following lung preservation with low-potassium dextran [10].

Table 7. Cause of 30-day mortality

\begin{tabular}{lcl}
\hline & EC $(\mathrm{n}=48)$ & $\operatorname{LPD}(\mathrm{n}=76)$ \\
\hline 30-day mortality, \% & 12.5 & 7.9 \\
IRI & 3 & 0 \\
Sepsis & 1 & 2 \\
Others & 2 & 4 \\
\hline
\end{tabular}

IRI = Ischemia reperfusion injury .
In more sophisticated studies dealing with the mechanisms of an improved graft function our group was able to show that low-potassium dextran as compared to EuroCollins leads to a significantly decreased lipid peroxidation of lung tissue, associated with a significant reduction of reperfusion injury [17].

These results are the basis of our decision to introduce low-potassium dextran (Perfadex) into clinical lung preservation. Our clinical results were able to demonstrate that the use of low-potassium dextran resulted in an improved primary graft function. The mortality rate of $8 \%$, caused by severe ischemia-reperfusion injuries, which was observed after the use of Euro-Collins solution was abolished [18]. This observation was confirmed by Keshavjee [19] and Haverich [20] and lead to a substitution of Euro Collins by LPD.

The follow-up of the transplant patients must show, whether a reduced ischemia-reperfusion injury and therefore improved immediate graft function may have its effect on long-term graft function. This paper gives an example, how experimental work on a clinically relevant problem can result in a successful transfer into clinical practice.

Improvement of Lung Preservation 


\section{References}

1 Hardy JD, Webb WR, Dalton ML Jr, Walker GR Jr: Lung homotransplantation in man: Report of the initial case. JAMA 1963;186:10651074.

2 Hosenpud JD, Bennett LD, Keck BM, Boucek MM, Novick RJ: The Registry of the International Society for Heart and Lung Transplantation: Eighteenth Official Report 2001. J Heart Lung Transplant 2001;20:805-815.

3 Burdine J, Hertz MI, Snover DC, Bolman RM: Heart-lung and lung transplantation: Perioperative pulmonary dysfunction. Transplant Proc 1991;23:1176-1177.

4 Haydock DA, Trulock EP, Kaiser LR, Knight SR, Pasque MK, Cooper JD: Management of dysfunction in the transplanted lung: Experience with seven clinical cases. Washington University Lung Transplant Group. Ann Thorac Surg 1992;53:635-641.

5 Keenan RJ, Griffith BP, Kormos RL, Armitage JM, Hardesty RL: Increased perioperative lung preservation injury with lung procurement by Euro-Collins solution flush. J Heart Lung Transplant 1991;10:650-655.

6 Kimblad PO, Sjoberg T, Massa G, Solem JO, Steen S: High potassium contents in organ preservation solutions cause strong pulmonary vasocontraction. Ann Thorac Surg 1991;52. 523-528.

7 Kimblad PO, Massa G, Sjoberg T, Steen S: Endothelium-dependent relaxation in pulmonary arteries after lung preservation and transplantation. Ann Thorac Surg 1993;56:13291333.
8 Steen S, Sjoberg T, Massa G, Ericsson L, Lindberg L: Safe pulmonary preservation for 12 hours with low-potassium-dextran solution. Ann Thorac Surg 1993;55:434-440.

9 Steen S, Kimblad PO, Sjoberg T, Lindberg L, Ingemansson R, Massa G: Safe lung preservation for twenty-four hours with Perfadex. Ann Thorac Surg 1994;57:450-457.

10 Müller C, Hoffmann H, Kur F, Fürst H, Munich Lung Transplant Group: Der Einfluss von low potassium dextrane (Perfadex) auf den Ischämie-Reperfusionsschaden nach experimenteller und klinischer Lungentransplantation. Langenbecks Arch Chir 1999; Forumband: $31-36$.

11 Warburg O: Wasserstoffübertragende Enzyme. Berlin, Sanger, 1948, pp 33-42.

12 Lamprecht W, Trautschold I: Adenosin-5'-Triphosphat: Bestimmung mit Hexokinase und Glukose-6-Phosphat-Dehydrogenase; in Bergmeyer HU (ed): Methoden der enzymatischen Analyse. 1974, pp 2151-2160.

13 Isselhard W, Merguet H: Metabolite des Glykolyse-Cyklus und des Adenylsäure-Phosphokreatine-Systems in schlagenden und durchbluteten Warmblüterherzen unter verschiedenen Versuchsbedingungen. Pflüger's Arch 1962;1: 211-235.

14 Kimblad PO, Steen S: Eliminating the strong pulmonary vasoconstriction caused by EuroCollins solution. Ann Thorac Surg 1994;58: 728-733.
15 Kimblad PO, Sjoberg T, Steen S: Pulmonary vascular resistance related to endothelial function after lung transplantation. Ann Thorac Surg 1994;58:416-420.

16 Maccherini M, Keshavjee SH, Slutsky AS, Patterson GA, Edelsohn JD: The effect of lowpotasium-dextran versus Euro-Collins solution for preservation of isolated type-II-pneumocytes. Transplantation 1991;52:621-626.

17 Sakamaki F, Hoffmann H, Müller C, Dienemann H, Messmer K, Schildberg FW: Reduced lipid peroxidation and ischemia-reperfusion injury after lung transplantation using lowpotassium dextran solution for lung preservation. Am J Respir Crit Care Med 1997;156: 1073-1081.

18 Müller C, Fürst H, Reichenspurner H, Briegel J, Groh J, Reichart B: Lung procurement by low potassium dextran and the effect on preservation injury. Transplantation 1999;68:1139_ 1143.

19 Fischer S, Matte-Martyn A, de Perrot M, Waddell TK, Sekine Y, Hutcheon M, Keshavjee S: Low-potassium dextran preservation solution improves lung function after human lung transplantation. J Thorac Cardiovasc Surg 2001; 121:594-596.

20 Struber M, Wilhelmi M, Harringer W, Niedermeyer J, Anssar M, Kunsebeck A, Schmitto JD, Haverich A: Flush perfusion with low potassium dextran solution improves early graft function in clinical lung transplantation. Eur J Cardiothorac Surg 1999;19:190-194. 